\title{
Perception of university students on unwanted pregnancy in south west Nigeria
}

\author{
Olaitan, O. 'Lanre Ph.D. \\ Department of Human Kinetics and Health Education \\ University of Ilorin, Nigeria \\ ABSTRACT
}

\begin{abstract}
This study investigated the perception of unwanted pregnancy among university students in south west Nigeria. A cross-sectional survey was conducted and data were analyzed on perception of unwanted pregnancy. The variables examined include, perception of the causes consequences and prevention of unwanted pregnancy. A multi-stage sampling technique was used to select 400 subjects and a structured questionnaire was used to collect data from the respondents. The findings revealed that all the three null-hypotheses generated were rejected, using Chi-square $\left(X^{2}\right)$ statistical method at $\propto=0.05$ level of significance. The findings showed that university students have significant perception of the causes, consequences and prevention of unwanted pregnancy. Based on the findings, recommendations were made such as; parent should give sufficient fund to their children; introduction and teaching of sex-education should be included in the school curriculum; adequate and functioning of family planning programs/clinics should be established in schools amongst others.
\end{abstract}

Keywords: University, Unwanted pregnancy, Perception

\section{INTRODUCTION}

Unwanted pregnancy constituted a major public health problem. Youths attract considerable attention all over the world, this may be as a result of their seemingly radical behaviour at home to parents, their peculiar stubbornness at school or simply because of their uniquely and future relevance to the society (Ajayi, 1996).

Unwanted pregnancy is unintended usually unplanned pregnancy, which may occur to unmarried lady or a teenager. Although, it could also occur to a married woman, but in this case, she may be on child-spacing or family planning practice. So, unwanted pregnancy either legally or illegally is a common problem in our society today.

Causes of unwanted pregnancy: The problem of unwanted pregnancy can be due to poverty, ignorance of the parents on sex education and lack of adolescent interest on sexuality and fertility in the school. According to Meddinus \& Johnson (2007), the causes of teenage pregnancy include the crave for money and materialism in the country; broken/separated homes, inadequate or absence of sex education, influence of pornographic materials, ignorance among the teenage girls on the use of contraceptives and the general moral laxity in the country.

Parents do not take time to teach the correct things about sex to their children. Mitchel (2007) in his studies pointed out that her respondents claimed to have learned about sexual matters from their friends, books or novels and from watching television. The knowledge that adolescents gained from friend, books, television, etc is usually grossly inadequate. Olayinka (1997) opined that most teenagers do not have knowledge on the nature of sex and reproduction. They do not have the experience or maturity it takes to avoid unwanted pregnancies, some of them may have access to contraceptives, but they may not know their correct uses or their possible side effects. As they do not get the family planning experts to recommend some contraceptives, their approach to self-medication may prove very depressing.

Oguntade (1992) explained that the type of films imported into the country e.g. (pornographic/blue films and romantic films). He also stated that schoolgirls become pregnant as a result of their exposure to romantic and blue films. This often affects most of them in their bid to model after or practicalise what they watch in the films. Planned Parenthood Federation of Nigeria (PPFN) (1990) in a paper presented on the introduction to family life education in Africa, one out of every six babies born between the year 1988-1989 were born to mothers under 20 years of age. This is the view of proportion particularly when placed alongside the proportion of teenage mothers in other third world countries such 
as Ghana and Kuwait where it was rated to be one out of twelve unwanted pregnancies of students as revealed in African Journal of Reproductive Health often lead to expulsion from school, thereby reducing employment options in later life.

\section{Consequences of unwanted pregnancy:} Furthermore, unwanted pregnancy poses health risks to the mother as well as to the children such as prematurity, low birth weight, birth injuries and damage can occur in the birth process that renders them infertile or endangers their lives. Abortion as most victims of unwanted pregnancy do, is often a frightful expensive operation, only the few who have enough money ever seek the services of qualified gynecologists while poorer girls either run to quacks or try to get rid of the pregnancy themselves by drinking toxic substance which brings about tragic result and death at times. Even when the abortion bid initially seems to have gone hitch-free its scars could still affect future pregnancies especially by heightening the risk of miscarriage and premature delivery.

School attendance becomes more difficult while nursing a baby, the teenage mother may be forced to drop out from school. Where she is abandoned into the boy or the man responsible for her pregnancy, such forced cohabitation arrangements hardly last. On the other hand, if she remains unmarried, her child may suffer neglect, abuse, abandonment or grow up to face some forms of social discrimination of stigmatization (Oguntade,1992).

Prevention of unwanted pregnancy: The most important prevention is to educate oneself about unwanted pregnancy and to be able to device methods of preventing the occurrence. The primary reason that youth who have never had intercourse give for abstaining from sex is that having sex would be against their religious or moral values. Others ways include desire to avoid pregnancy, fear of contacting a sexually transmitted disease (STD), and not having met the appropriate partner. Rossenfield (2003) listed some important tips to follow in order to help prevent girl from becoming pregnancy such as: discourage early, steady dating; encourage friendship and group activities; counselling programme should be established and extended to the grassroot by professional health care sectors to protect unwanted pregnancy; family planning programme and contraceptives should be made available to everybody especially the adolescents in order to prevent unsafe abortion and unwanted pregnancies; introduction and teaching of sex education in schools by the teachers, health educators or health workers and at homes by parents.

Statement of the Problem: Too early age to be in the university and where both young and old are staying together in the same hostel is a problem, because the younger ones are watching the older ones as they involve in sexual relationships with men and they also try to experiment such act, These inexperience young ones are at high risk of unwanted pregnancy. Unwanted pregnancy has been described as a very traumatic experience for the students in the lights of its economic, psychological, social emotional, medical and educational system (Mitchel, 2007) Nigeria adolescent mothers suffer severe complications during delivery that result in higher morbidity and mortality both to themselves and their children, there are lot of criminal abortion been committed by teenagers due to their involvement in early sexual experimentation which leads to unwanted pregnancy(Chum, 1995) Unprotected sexual activity among teenagers result into sexually transmitted diseases such as HIVIAIDS infection, most youths who have unwanted pregnancies often seek advice either from equally ignorant peers or their male consort so as to conceal the incident from their parents and school authorities.

\section{Objectives of the study:}

To investigate university students' perception on the causes of unwanted pregnancy, to find out university students' perception on the consequences unwanted pregnancy. To examine university students' perception on the preventive measures for unwanted pregnancy.

\section{Research Hypotheses}

University students will not significantly perceive what the causes of unwanted pregnancy are. University students will not significantly perceive what the consequences of unwanted pregnancy are. University students will not significantly perceive what the preventions of unwanted pregnancy are.

\section{METHODOLOGY}

A multi-stage sampling method was adopted to select 400 respondents from the undergraduate students of universities. Close-ended questionnaires were administered to the respondents. Descriptive and inferential statistics of Chi-square $\left(\chi^{2}\right)$ at 0.05 level of significance were employed to analyse the data obtained using SPSS 16.0. 


\section{RESULTS AND DISCUSSIONS}

Table 2 shows that the calculated $x^{2}$ value of 67.2 is greater than the critical value of 21.03 , in that case, the hypothesis one was rejected, which means the university students significantly perceived the statements above as the causes of unwanted pregnancy in this order, thus: $89.3 \%$ said that unwanted pregnancy could be as a result of not being exposed to sex education, $88 \%$ felt that it is caused by peer influence, $65 \%$ perceived that poverty can lead to unwanted pregnancy, $53.8 \%$ believed that ignorance about the use of contraceptives could cause it and $52 \%$ perceived that the cause is lack of parental care. This is in line with the findings of Meddinus \& Johnson (2007) who opined that the causes of unwanted pregnancy include crave for money and materials. They further said that broken/separated homes, inadequate or absence of sex education, general moral laxity and influence of pornographic materials are factors. It also corroborates with the findings of Hurlock (1999) who discovered that sexual irresponsibility among some children could be as a result of peer group influence.

In the second hypothesis, the calculated value of 97.3 is greater than the critical value of 21.03 . The null hypothesis was therefore rejected, that is, students of these universities significantly perceived the statements above as the consequences of unwanted pregnancy, thus: it may cause low economic status for the victim (95.8\%), 69.5\% of the respondents perceived that unwanted pregnancy may lead to many health problems, $62 \%$ opined that it could cause termination of educational career, $38.5 \%$ believed it may lead to child neglect and abandonment and $33 \%$ asserted that it may lead to shame and withdrawal from the society or even a suicidal attempt. In the findings on the perception on the consequences, majority of the respondents said that unwanted pregnancy might result into child neglect or abandonment. This corroborates with Olayinka (1997) who postulated that, if the girl is lucky to have parents who understand and sympathetic to her plight, the child may be cared for by her parents. But the problem does not end there; the child may later turn out to be a nuisance and may insist on knowing his/her father. Closely associated with the above point is that the mother too may reject or abandon the child, since it is the outcome of an unwanted pregnancy. This may be the reason why some will abandon young babies in nooks and crannies of our society. This accounts for why many children are in the motherless homes. Also the finding reveals that many health problems could emanate from unwanted pregnancy. This is in support of Ryan \& Schneider (2007) that teenage obstetric complications are many, there are risks of prematurity and neo-natal deaths in infants of adolescents as well as excessive weight gain, prolonged labour, cervical laceration, increased frequency of cesarean section and increase incidence of prematurity, nutritional deficiencies, anaemia and sexual transmitted diseases. Also, many believed that it could lead to termination of educational career as seen by Oguntade (1992) who opined that unwanted pregnancy can cause a girl to be expelled from school or dropout of the school. This is so because child bearing demand a lot attention and time that may be tedious for a girl who has to carry the pregnancy for nine months. He further said pregnancy thus interfere with her schooling unless her parent and the spouse are also educationally ambitious and are supportive of the girl's goal. In few African countries the pregnant girls may be given an option of withdrawing from school to deliver the baby and return back to school after a year absence

For hypothesis three, the calculated value of 46.7 is higher than critical value of 21.03, the null-hypothesis was therefore rejected, indicating that the statements above are significant as perceived preventive measures for unwanted pregnancy as follows: $97.5 \%$ perceived that adequate knowledge about sexual and reproductive health would help prevent the menace of unwanted pregnancy, $83.8 \%$ understood that abstaining sex would help to prevent unwanted pregnancy, $74.3 \%$ perceived that introduction and teaching of sex education in schools could prevent unwanted pregnancy, $61.8 \%$ said inculcation of religion and moral values into the children would help prevent unwanted pregnancy and $60.5 \%$ felt that establishing family planning programs/clinics in schools could prevent it. The perception of university students on the prevention of unwanted pregnancy was quite high as they opined that knowledge of sexual and reproductive health would help prevent unwanted pregnancy. This supports the findings of Rossenfield (2003) that introduction and teaching of sex education in school by teachers, health educators or health workers will improve students' knowledge of sexual and reproductive health and that it could help them to prevent unwanted pregnancy. Although, he was of the opinion that parents have major role to play by monitoring and supervising their wards. Some of the respondents also opined that, abstinent, inculcation of religion and moral values and 
establishment of family planning programs/clinics in schools would go a long way preventing unwanted pregnancy.

CONCLUSIONS AND RECOMMENDATIONS: From the analysis of data and interpretations of the findings, there are evidences to show that three objectives were raised and three null-hypotheses were generated and tested using chi-square $\left(X^{2}\right)$ statistics. From the analyses it was concluded that, university students have significant perception of what causes, consequences and perception of unwanted pregnancy are.

Based on the findings, it was recommended that, sex education should be entrenched in the school curriculum and should be encouraged at homes by parents or guardians, parents should provide adequate fund for their children and wards so that they are not lured into immoral sexual activities such as prostitution, "aristo" or "sugar daddies", students should take note of the type of friends they move with and should caution themselves from moving alone especially late in the night to avoid rape, and students should abstain from sexual experimentation, where it is not possible they should be conscious of various contraceptives available and make good use of them.

The Bio-data were presented by frequency counts and percentages below.
Table 1: Socio-demographic characteristics of the students by gender, age, faculty, family type, religion, friendship and coitus experience

$\mathrm{N}=\mathbf{4 0 0}$

\begin{tabular}{|c|c|c|}
\hline Gender & $\begin{array}{l}\text { Frequ- } \\
\text { ency }\end{array}$ & $\begin{array}{l}\text { Percen- } \\
\text { tage (\%) }\end{array}$ \\
\hline Male & 160 & 40 \\
\hline Female & 240 & 60 \\
\hline $\begin{array}{l}\text { Age (in years) } \\
<19\end{array}$ & 20 & 5 \\
\hline $20-19$ & 180 & 45 \\
\hline $30-35$ & 160 & 40 \\
\hline University I Department & 40 & 10 \\
\hline $\begin{array}{l}\text { UNILAG History } \\
\text { Surveying }\end{array}$ & $\begin{array}{l}50 \\
50\end{array}$ & $\begin{array}{l}15.5 \\
12.5\end{array}$ \\
\hline Mass Communication & 50 & 12.5 \\
\hline Computer Science & 50 & 12.5 \\
\hline $\begin{array}{l}\text { Zoology } \\
\text { Statistics }\end{array}$ & $\begin{array}{l}50 \\
50\end{array}$ & $\begin{array}{l}12.5 \\
12.5\end{array}$ \\
\hline $\begin{array}{l}\text { Pharmacy } \\
\text { Geography }\end{array}$ & $\begin{array}{l}50 \\
50\end{array}$ & $\begin{array}{l}12.5 \\
12.5\end{array}$ \\
\hline $\begin{array}{l}\text { Family type } \\
\text { Single parent }\end{array}$ & $\begin{array}{l}144 \\
256\end{array}$ & $\begin{array}{l}36 \\
64\end{array}$ \\
\hline $\begin{array}{l}\text { Religion } \\
\text { Christianity } \\
\text { Islam }\end{array}$ & $\begin{array}{l}216 \\
1.84\end{array}$ & $\begin{array}{l}54 \\
546\end{array}$ \\
\hline $\begin{array}{l}\text { Friends (many) } \\
\text { Yes } \\
\text { No }\end{array}$ & $\begin{array}{l}174 \\
226\end{array}$ & $\begin{array}{l}43.5 \\
56.5\end{array}$ \\
\hline $\begin{array}{l}\text { Coitus experience } \\
\text { Having sexual experience } \\
\text { Not having sexual experience }\end{array}$ & $\begin{array}{l}222 \\
198\end{array}$ & $\begin{array}{l}44.5 \\
55.5\end{array}$ \\
\hline
\end{tabular}


Table 2: Contingency table and Distribution of Respondents on perceived causes, consequences and prevention of unwanted pregnancy in percentages

\begin{tabular}{|c|c|c|c|c|c|}
\hline S/ & Statement & $\begin{array}{c}\% \\
\text { Positive }\end{array}$ & $\%$ Negative & Calc. ${ }_{\text {val }} X^{2}$ & $\begin{array}{l}\text { Decision on } \\
\text { Ho }\end{array}$ \\
\hline & $\begin{array}{l}\text { Perception on the causes of unwanted } \\
\text { preqnancy }\end{array}$ & & & \multirow{6}{*}{67.2} & \multirow{6}{*}{ Rejected } \\
\hline 1 & Poverty can lead to unwanted pregnancy & $65 \%$ & $35 \%$ & & \\
\hline 2 & $\begin{array}{l}\text { Lack of parental care and necessary advice lead to } \\
\text { unwanted pregnancy }\end{array}$ & $52 \%$ & $48 \%$ & & \\
\hline 3 & $\begin{array}{l}\text { Ignorance about the use of contraceptives leads to } \\
\text { unwanted pregnancy. }\end{array}$ & $53.8 \%$ & $46.2 \%$ & & \\
\hline 4 & Peer influence leads to unwanted pregnancy & $88 \%$ & $12 \%$ & & \\
\hline \multirow[t]{2}{*}{5} & $\begin{array}{l}\text { Unwanted pregnancy is common among those that } \\
\text { are not exposed to sex education }\end{array}$ & $89.3 \%$ & $10.7 \%$ & & \\
\hline & $\begin{array}{l}\text { Perception on the consequences of unwanted } \\
\text { pregnancy }\end{array}$ & & & \multirow{6}{*}{97.2} & \multirow{6}{*}{ Rejected } \\
\hline 6 & $\begin{array}{l}\text { Unwanted pregnancy could lead to many health } \\
\text { problems }\end{array}$ & $69.5 \%$ & $30.5 \%$ & & \\
\hline 7 & $\begin{array}{l}\text { Unwanted pregnancy can result into termination of } \\
\text { educational career }\end{array}$ & $62 \%$ & $38 \%$ & & \\
\hline 8 & $\begin{array}{l}\text { Unwanted pregnancy may lead to child neglect or } \\
\text { abandonment }\end{array}$ & $38.5 \%$ & $61.5 \%$ & & \\
\hline 9 & $\begin{array}{l}\text { Unwanted pregnancy may lead to low economic } \\
\text { status }\end{array}$ & $95.8 \%$ & $4.2 \%$ & & \\
\hline \multirow[t]{2}{*}{10} & $\begin{array}{l}\text { Unwanted pregnancy may lead to shame and } \\
\text { withdrawal from the society or even suicidal attempt. }\end{array}$ & $33 \%$ & $67 \%$ & & \\
\hline & $\begin{array}{l}\text { Perception on the prevention of unwanted } \\
\text { pregnancy }\end{array}$ & & & \multirow{6}{*}{46.7} & \multirow{6}{*}{ Rejected } \\
\hline 11 & $\begin{array}{l}\text { Abstaining from sex would help prevent unwanted } \\
\text { pregnancy }\end{array}$ & $83.8 \%$ & $16.2 \%$ & & \\
\hline 12 & $\begin{array}{l}\text { Adequate knowledge about sexual and reproductive } \\
\text { health would help prevent unwanted pregnancy }\end{array}$ & $97.5 \%$ & $2.5 \%$ & & \\
\hline 13 & $\begin{array}{l}\text { Inculcating religions and moral value into children } \\
\text { would help prevent unwanted pregnancy }\end{array}$ & $61.8 \%$ & $38.2 \%$ & & \\
\hline 14 & $\begin{array}{l}\text { Unwanted pregnancy can be prevented by } \\
\text { establishing family planning program/clinics in } \\
\text { schools }\end{array}$ & $60.5 \%$ & $39.5 \%$ & & \\
\hline 15 & $\begin{array}{l}\text { Introduction and teaching of sex education in } \\
\text { schools would help prevent unwanted pregnancy }\end{array}$ & $74.3 \%$ & $25.7 \%$ & & \\
\hline
\end{tabular}

$\mathrm{P} \leq 0.05$, Crt value $=21.03 \mathrm{REFERENCES}$

\section{REFERENCES}

Adebayo, O.A. Teenager Pregnancy: who is at fault? Contribution to a symposium organized by PAN African Christian Women Alliance (PACWA), Kwara State Branch 1992.

Ajayi, A.A. (1996). Sexual beh+aviour of adolescent, African Journal of Reproductive Health,, No.5, pp 1317.

Chum, J. Health and teenage pregnancy in Nigeria. Lagos Medical Journal, Vol. 2, No. 1, pp. 9-12, 1995.

Hurlock, B.M. Teenagers, sex and contraceptives: Family Planning Perspectives Vol . 5, No. 1, 38-41, 1999.

Meddinus, U.V and Johnson, T.C. Factor of associated with unwanted pregnancy. Retrieved July 15, 2007 from http://www.Pregnancy.org.

Mitchel, J, Sexual Matters and peers. Retrieved July 15, 2007, form http:/www. Health all refers.Com
Oguntade, O, Sexual behaviour of Nigerian students. An unpublished thesis, University of Ilorin 1992.

Olayinka, M.S (1997). Sex education and marital guidance. Lagos: Lantern Books Liferamed Ltd.

Planned parenthood Federation of Nigeria (1990). Unwanted pregnancy and the proportion in Nigeria today. 11(2):6-7.

Rossenfield, W.A.(2003). Understanding your teens $\left(2^{\text {nd }}\right.$ ed.), New York: McGraw-Hill.

Ryan, G.M \& Scheinder J.M (2007), Teenage obstetric complications teenage department of Public Health Clinical Obstetrics and gynaecology vol 2 (4) pp 1624.

Teenage conception (2007). Retrieved July 15, from http://www.Anglicarevic.org/all/parentzone/southern/ti psheet 201-4 